\title{
PENGARUH ORIENTASI BUDAYA PENGHINDARAN KETIDAKPASTIAN TERHADAP GAYA BELANJA PADA WISATAWAN NUSANTARA
}

\section{Baiq Handayani Rinuastuti ${ }^{1}$, Rusdan ${ }^{2}$, Junaidi Sagir ${ }^{3}$ dan Darwini ${ }^{4}$}

\author{
${ }^{1}$ Master of Management Program, Mataram University, Indonesia \\ E-mail : hrinuastuti@unram.ac.id \\ ${ }^{2}$ Faculty of Economics and Business, Mataram University, Indonesia. \\ ${ }^{3}$ Faculty of Economics and Business, Mataram University, Indonesia. \\ ${ }^{4}$ Faculty of Economics and Business, Mataram University, Indonesia.
}

\begin{tabular}{|c|c|}
\hline ARTICLE INFO & ABSTRACT \\
\hline $\begin{array}{l}\text { Keywords: } \\
\text { Shopping style, uncertainty avoidance, } \\
\text { domestic travelers } \\
\text { How to cite: } \\
\text { Rinuastuti, HB, Rusdan, Sagir, J, Darwini } \\
\text { (2018). Pengaruh Orientasi Budaya } \\
\text { Penghindaran Ketidakpastian Terhadap } \\
\text { Gaya Belanja Pada Wisatawan Nusantara. } \\
\text { JMM UNRAM, 7(4), } 57-69 \\
\text { DOI: } \\
\text { 10.29303/jmm.v7i4.346 }\end{array}$ & $\begin{array}{l}\text { This research aim is to get a depth understanding to the } \\
\text { potential of difference in shopping style related to the culture } \\
\text { orientation to avoid uncertainty in the tourist group. This } \\
\text { research was conducted in three tourist sites, namely: Senggigi } \\
\text { Beach, Gili Terawangan, and Kuta Beach. With Manova } \\
\text { analysis known that tourists who have high uncertainty } \\
\text { avoidance orientation tend to have decision-making style that } \\
\text { prioritizes; quality, value, well-known brand, loyal to the } \\
\text { brand, and confusion because of the many options. While at } \\
\text { Travelers who have low uncertainty avoidance orientation tend } \\
\text { to have a decision-making style that characterized expenditure: } \\
\text { fashion consciousness, orientation recreational, and impulsive. } \\
\text { By knowing the relationship between uncertainty avoidance } \\
\text { cultural orientation and style tourist spending will bring } \\
\text { enormous benefits to the tourism industry and government in } \\
\text { promoting the activities of tourist spending, especially for the } \\
\text { domestic market segment. } \\
\text { Tujuan penelitian ini adalah untuk mendapatkan pemahaman } \\
\text { yang mendalam terhadap potensi perbedaan gaya belanja yang } \\
\text { terkait dengan orientasi budaya untuk menghindari } \\
\text { ketidakpastian dalam kelompok wisatawan. Penelitian ini } \\
\text { dilakukan di tiga lokasi wisata, yaitu: senggigi beach, termasuk } \\
\text { gili terawangan dan pantai kuta. Dengan analisis manova tahu } \\
\text { bahwa wisatawan yang memiliki ketidakpastian tinggi } \\
\text { penghindaran orientasi cenderung memiliki gaya pengambilan } \\
\text { keputusan yang mengutamakan; kualitas, nilai, merek terkenal, } \\
\text { setia kepada merek dan kebingungan karena banyaknya pilihan. } \\
\text { Sementara pada wisatawan yang memiliki orientasi } \\
\text { penghindaran ketidakpastian rendah cenderung memiliki } \\
\text { keputusan-membuat gaya yang dicirikan pengeluaran : Mode } \\
\text { kesadaran, orientasi rekreasi dan impulsif. Dengan mengetahui } \\
\text { hubungan antara ketidakpastian penghindaran budaya }\end{array}$ \\
\hline
\end{tabular}




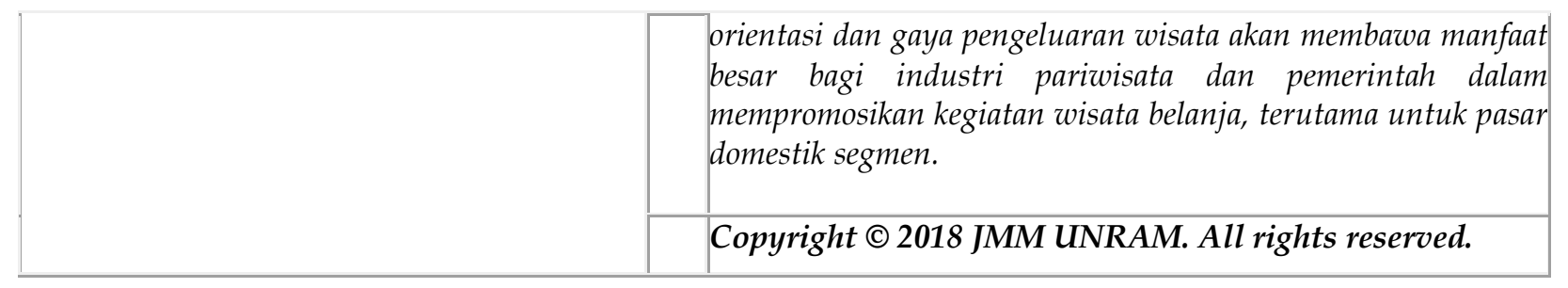

\section{PENDAHULUAN}

Belanja menjadi salah satu kegiatan penting bagi wisatwan. Belanja telah menjadi kontributor ekonomi yang signifikan kepada industri pariwisata dan ritel dan menjadi kategori pengeluaran yang paling signifikan pada liburan dan perjalanan. Penelitian menunjukkan bahwa wisatawan menghabiskan sekitar sepertiga dari total pengeluaran pariwisata mereka untuk belanja (Littrell,Baizerman, Kean, Gahring, Niemeyer, Reilly, dan Stout, 1994).

Belanja, sebagai bagian integral dari pengalaman banyak wisatawan, dapat menjadi salah satu alasan utama mengapa orang perjalanan (Timotius dan Butler, 1995), dan sering berfungsi sebagai komponen kunci dari kombinasi produk atau sumber daya tujuan pariwisata (Dimanche, 2003). Meskipun penting dan berkontribusi untuk tujuan pariwisata, peran belanja sebagai kegiatan wisata yang telah lama kurang terwakili dalam literatur pariwisata; dan studi tentang belanja pariwisata masih terbatas (Jansen-Verbeke, 1991, 1998; Yu dan Littrell, 2003; Oh, Cheng, Lehto, dan O'Leary, 2004; Heung dan Cheng, 2000).

Perilaku belanja wisatawan dalam konteks pariwisata merupakan suatu kegiatan yang unik, berbeda dari belanja sehari-hari (Ya et al., 2004). Jung Oh (2007) menyatakan dalam konteks pariwisata, perilaku orang-orang berbelanja berbeda pada saat berlibur dibandingkan dengan pola normal mereka di rumah. Beberapa pembeli yang tidak antusias untuk berbelanja di tempat asal menunjukkan perilaku berinvestasi sejumlah besar uang dan waktu untuk belanja selama perjalanan liburan. Karena itu, ketika bepergian, perilaku belanja individu jauh berbeda dari aktivitas belanja di rumah (Kent et al., 1983;. Belk 1988; Butler 1991; Brown 1992;. Timothy et al., 1995; Buhalis 2000 dalam Jung Oh, 2007). Oleh karena itu, penting untuk menganalisis karakteristik perilaku wisata belanja, misalnya, makna, struktur, harapan, pola preferensi perilaku wisata belanja, dan gaya belanja wisatawan. (Jansen-Verbeke, 1991, 1998; Yu dan Littrell, 2003; Oh et al, 2004;. Belk, 1988).

Literatur tentang gaya pengambilan keputusan telah memiliki sejarah yang panjang di dalam penelitian pemasaran dan perilaku konsumen. Gaya pengambilan keputusan (consumer decision-making styles, CDMS) yang disebut dengan nama CSI adalah salah satu upaya awal untuk mengukur orientasi belanja secara sistematis (Sproles dan Kendall,1986) dengan menggabungkan ke tiga dimensi tersebut. CSI membagi gaya pengambilan keputusan dari para pembelanja menjadi 8 kategori: (1) Perfeksionisme/kesadaran akan kualitas, (2) Harga dan kesadaran nilai, (3) Kebingungan karena terlalu banyak pilihan, (4) kecenderungan impulsif dan ceroboh, (5) Kesadaran merek,(6) Kesadaran akan hal baru/fashion, (7) Orientasi rekreasional dan hedonistik, dan (8) Kesetiaan merek/belanja habitual.

Dalam konteks kegiatan pariwisata, penelitian terhadap perilaku konsumen telah dilakukan untuk menyelidiki berbagai aspek dari wisatawan, dan berusaha untuk menjelaskan mengapa mereka melakukan apa yang mereka lakukan (Pearce, 2005). Wisatawan berkunjung dan memasuki suatu daerah dengan latar belakang kehidupan yang selama ini membentuk perilaku dan menjadi karakteristik mereka. Perilaku yang sudah terbentuk lama tidak begitu saja mereka lepaskan. Budaya mempunyai pengaruh yang kuat 
terhadap perilaku konsumen (Schiffman \& Kanuk, 2007) dan penentu fundamental dari keinginan dan perilaku seseorang (Kotler, 2003).

Hofstede (1983) menyatakan bahwa beberapa dimensi budaya lebih berpengaruh dibandingkan lainnya dalam situasi tertentu. Secara khusus, Hofstede menunjukkan bahwa penghindaran ketidakpastian secara potensial merupakan dimensi budaya paling signifikan dalam situasi internasional sehubungan dengan toleransi resiko dan perilaku yang sudah ditentukan, seperti dicatat oleh Yavas (1990) dalam Money dan Crotts (2003). Penelitian Rinuastuti (2014) menunjukkan pula bahwa budaya penghindaran ketidakpastian menjadi variabel yang berkontribusi tinggi dalam menjelaskan perilaku wisatawan termasuk pula saat wisatawan berbelanja.

Penghindaran ketidakpastian yang tinggi mengarahkan wisatawan pada perilaku yang cenderung menghindar dari situasi yang penuh ketidakpastian dan resiko. Semakin besar keinginan untuk menghindari ketidakpastian, semakin banyak orang mencari keteraturan, konsistensi, struktur, prosedur formal dan hukum. Sebaliknya pada penghindaran ketidakpastian yang rendah cenderung lebih aktif, agresif, emosional, cenderung berani mencoba hal-hal yang baru, inovatif dan menantang. Belanja sebagai kegiatan yang tidak bisa dipisahkan dalam melakukan kegiatan pariwisata tidak hanya memberikan pengalaman yang menyenangkan, akan tetapi dapat pula menimbulkan resiko. Oleh karena itu terdapat kemungkinan adanya keterkaitan orientasi nilai budaya penghindaran ketidakpastian dengan gaya belanja pada wisatawan.

Nusa Tenggara Barat (NTB) sebagai salah satu destinasi wisata yang sedang berkembang, tentunya harus memahami berbagai hal yang berkaitan dengan perilaku wisatawan. Disamping wisatawan mancanegara, kunjungan wisatawan Nusantara juga memiliki kontribusi penting bagi perkembangan ekonomi pada daerah tujuan wisata. Berdasarkan penelitian UN-WTO kontribusi pariwisata dalam negeri dibandingkan dengan kontribusi pengunjung internasional mencapai $60 \%$ dari jumlah pendapatan pariwisata (www.newsletter-pariwisataindonesia.com).

Selama ini pariwisata domestik dianggap sebagai "shock absorber" yang dapat meredam dampak negatif dari krisis yang timbul, atau menjadi "cadangan" yang diandalkan untuk melindungi produk wisata, terutama akomodasi, membantu mempertahankan dan memberikan pekerjaan kepada orang-orang yang matapencahariannya tergantung pada industri pariwisata (www.newsletterpariwisataindonesia.com). Temuan UN-WTO tersebut menunjukkan bahwa pariwisata domestik tidak hanya sekedar "cadangan" saja, melainkan menjadi sumber potensial yang memberikan kontribusi positif bagi pendapatan di sektor pariwisata. Oleh karena itu, sudah selayaknya diperlukan program dan kebijakan pariwisata khususnya di daerah wisata untuk lebih memperhatikan wisatawan dalam negeri.

Untuk lebih meningkatkan kegiatan belanja dari kelompok wisatawan tersebut, perlu kiranya dilakukan kajian untuk mendapatkan pemahaman yang lebih mendalam tentang potensi perbedaan pada gaya belanja terkait dengan tinggi rendahnya orientasi budaya penghindaran ketidakpastian pada kelompok wisatawan tersebut.

\section{HASIL PENELITIAN TERDAHULU}

Penelitian latar belakang budaya terhadap perilaku wisatawan mendapat perhatian yang semakin besar dari bidang akademis selama beberapa tahun terakhir.. Namun sampai sejauh ini masih sedikit sekali penelitian yang sudah menyelidiki tentang latar belakang budaya di dalam pengambilan keputusan konsumen. Penelitian Fan dan Xiao (1998); Hiu, Siu, Wang dan Chang (2001); Lysonski, Durvasula dan Zotos (1996) menunjukkan tentang adanya perbedaan budaya pada gaya pengambilan keputusan konsumen untuk pembelian 
produk fashion. Penelitian-penelitian tersebut dilakukan dengan mengidentifikasi gaya pengambilan keputusan dari beberapa kelompok konsumen dengan latar belakang budaya yang berbeda.

Penelian Leo, Bennett dan Härtel (2005), dilakukan dengan menguji prediksiprediksi empiris yang mengintegrasikan konsep CSI dengan tipologi budaya Hofstede pada responden Singapura dan Australia. Penelitian ini mengindikasikan bahwa ada perbedaan yang signifikan antar negara dalam hal gaya pengambilan keputusan untuk kepekaan merek, inovasi dan kebingungan karena terlalu banyak pilihan, dimana perbedaan yang paling besar adalah untuk inovasi. Perilaku belanja inovatif didapati lebih tinggi untuk sampel dari Singapura daripada untuk sampel dari Australia. Temuan ini selaras dengan argumen bahwa orang Singapura adalah lebih inovatif dalam berbelanja karena level keengganan terhadap ketidakpastian yang lebih rendah (Hofstede, 2001; Lower dan Corkindale, 1998; Spears, Lin dan Mowen, 2001). Selain itu pada kesetiaan merek menunjukkan bahwa budaya yang memiliki keengganan terhadap ketidakpastian yang besar (seperti Australia) akan lebih menyukai hal-hal yang sudah mereka kenal dengan baik/familiar dan enggan mengambil resiko (Yau, 1988).

Beberapa penelitian tersebut dilakukan pada konteks gaya pengambilan keputusan belanja untuk kebutuhan barang tidak dalam kegiatan perjalanan wisata.Untuk menambah wawasan keilmuan terkait dengan kegiatan belanja perlu dilakukan kajian yang lebih mendalam terhadap latar belakang budaya wisatawan dan gaya pengambilan keputusan dalam berbelanja.Terlebih lagi kegiatan belanja memberi kontribusi bagi pendapatan destinasi dan merupakan kegiatan yang unik dan berbeda dari kegiatan belanja di tempat asal.

\section{KAJIAN LITERATUR}

\subsection{Gaya Pengambilan Keputusan Konsumen di Dalam Berbelanja.}

Sproles dan Kendall (1986) mengkombinasikan pendekatan di atas dengan beberapa ciri tambahan untuk menyusun daftar dari gaya pengambilan keputusan (consumer decisionmaking styles, CDMS) yang disebut dengan nama CSI. Ini adalah salah satu upaya awal untuk mengukur orientasi belanja secara sistematis. Sproles dan Kendall (1986:79) mendefinisikan CSI sebagai: sebuah gaya pengambilan keputusan konsumen didefinisikan sebagai orientasi mental dan kognitif secara berpola terhadap belanja dan pembelian, yang terus menerus mendominasi pilihan konsumen ... ciri-ciri ini adalah selalu ada, bisa diprediksi, dan merupakan faktor penggerak utama di dalam pengambilan keputusan. Pada intinya yang dimaksud di sini adalah kepribadian konsumen yang relatif bertahan lama, mirip seperti konsep umum tentang kepribadian manusia dalam psikologi.

CSI membagi gaya pengambilan keputusan dari para pembelanja menjadi 8 kategori: perfeksionisme/kesadaran akan kualitas, harga dan kesadaran nilai, kebingungan karena terlalu banyak pilihan, kecenderungan impulsif dan ceroboh, kesadaran merek, kesadaran akan hal baru/fashion, orientasi rekreasional dan hedonistik dan kesetiaan merek/belanja habitual. Ke delapan gaya ini adalah karakteristik mental yang paling dasar dari pengambilan keputusan konsumen dan tiap-tiap gaya ini merepresentasikan pendekatan mental dari konsumsi (Sproles dan Kendall, 1986). Gaya-gaya belanja ini juga memiliki orientasi kognitif dan orientasi afektif, seperti kesadaran kualitas dan kesadaran akan fashion. Pengetahuan semacam ini sangat penting untuk mengidentifikasi segmen-segmen konsumen yang memiliki kesamaan sikap dalam berbelanja (Lysonski dkk., 1996). 


\subsection{Budaya Penghindaran Ketidakpastian}

Uncertainty Avoidance, adalah sejauh mana masyarakat, organisasi, atau kelompok bergantung dari norma-norma sosial, aturan, dan prosedur untuk mengurangi ketidakpastian peristiwa masa depan. Penghindaran ketidakpastian melibatkan tingkat perasaan tidak nyaman dengan lingkungan yang tidak pasti dan ambigu. Budaya yang memiliki penghindaran ketidakpastian yang rendah cenderung lebih aktif, agresif, emosional, cenderung berani mencoba hal-hal yang baru, inovatif dan menantang. Sebaliknya, budaya yang memiliki penghindaran ketidakpastian tinggi cenderung kontemplatif, kurang agresif, tidak emosional, resisten untuk menerima perubahan dan cenderung untuk mematuhi hukum yang ada, peraturan, formalitas, otoritas, dan terakhir untuk mengadopsi teknologi baru.

\section{PENGEMBANGAN HIPOTESIS}

Perbedaan orientasi penghindaran ketidakpastian pada individu akan menghasilkan perbedaan nilai yang diyakini oleh individu.Sproles dan Kendall (1986) telah mengidentifikasi "perfeksionisme", yaitu gaya belanja pertama dalam CSI, sebagai preferensi dari konsumen yang mencari kualitas tertinggi dalam produk. Konsumen yang peka kualitas (quality conscious) akan mencari produk dengan kualitas terbaik dengan cara berbelanja secara sistematis dan seksama (Sproles dan Kendall, 1986). Keinginanan akan produk yang berkualitas, "perfeksionisme", besar kemungkinan dilakukan oleh individu dengan penghindaran ketidakpastian tinggi.

Gaya berikutnya, yaitu kesadaran harga atau kesadaran nilai, adalah tingkat sejauh mana konsumen memperhatikan harga produk dan nilai yang sepadan dengan uang (value for money). Para konsumen yang memiliki kesadaran harga yang lebih tinggi akan lebih keras usahanya untuk mendapatkan nilai terbaik bagi uang mereka dan kemungkinan besar akan melakukan perbandingan dalam berbelanja. Resiko ketidaksesuaian manfaat dengan pengorbanan yang dikeluarkan bisa saja muncul dalam kegiatan belanja. Karena itu bagi individu yang berorientasi pada penghindaran ketidakpastian tinggi cenderung untuk menunjukkan gaya belanja yang peka terhadap harga, yaitu "keengganan/ ketidakbersediaan" (unwillingness) dari pembeli untuk membayar harga yang lebih tinggi untuk sebuah produk dan/atau "fokus secara eksklusif" semata-mata pada membayar harga rendah (Lichtenstein, Ridgway dan Netemeyer, 1993:235).

Kemudian, konsumen yang "bingung karena terlalu banyak pilihan" akan memperhatikan banyak merek dan banyak toko yang hendak mereka pilih tapi mengalami kesulitan di dalam membuat keputusan karena mereka mengalami kelebihan beban informasi (information overload). Individu yang berorientasi pada penghindaran ketidakpastian tinggi akan sulit menentukan pilihan karena banyaknya stimulus dan informasi yang dihadapinya.

Pengambilan keputusan secara peka terhadap merek merujuk pada orientasi konsumen yang cenderung untuk membeli produk yang mahal dan memiliki merek terkenal. Merek (brand) terkenal adalah jaminan terhadap kualitas dari sebuah produk. Bagi individu dengan orientasi penghindaran ketidakpastian tinggi akan merasa lebih aman dan nyaman untuk lebih peka terhadap merek yang sudah ternama, sehingga bisa menghindari mereka dari resiko yang mungkin ada pada sebuah produk.

Kesetiaan merek (gaya pengambilan keputusan yang setia pada merek). adalah ukuran dari tingkat sejauh mana konsumen melakukan pembelian sebagai kebiasaan (habit) dan terus bertahan pada merek atau toko favorit mereka (Sproles dan Kendall, 1986). Kesetiaan merek adalah sebuah strategi untuk mengurangi resiko, dan ini konsisten dengan dimensi UAI(keengganan terhadap ketidakpastian) dari Hofstede (2001) karena perilaku 
menghindari ketidakpastian akan memperbesar keengganan (aversion) terhadap resiko (Yau, 1988).

Berdasarkan uraian tersebut konsumen yang lebih condong memiliki orientasi penghindaran ketidakpastian tinggi akan memiliki kesadaran kualitas, harga, kebingungan karena banyaknya pilihan, kesadaran merek, dan memiliki orientasi kesetiaan merek atau habitual di dalam gaya belanja mereka:

H1; Konsumen yang memiliki kecenderungan orientasi budaya penghindaran ketidakpastian tinggi akan cenderung untuk memiliki gaya pengambilan keputusan yang bercirikan: (a) mementingkan kualitas, (b) kesadaran harga,(c) kebingungan karena pilihan yang terlalu banyak, (d)kesadaran merek, dan (e)kesetiaan merek.

Konsumen yang berorientasi pada penghindaran ketidakpastian rendah suka akan hal yang baru dan cenderung untuk memiliki sikap yang santai terhadap kehidupan, berani mengambil resiko dan melakukan hal-hal yang bisa memberikan kesenangan tanpa berpikir banyak atau berpikir panjang (Zuckerman, 1979). Zuckerman (1979) mendapati bahwa para pencari sensasi ini bersifat impulsif, yaitu cenderung untuk bertindak berdasarkan kemauan yang dirasakan saat itu juga. Para pemikir dengan sensasi tinggi ini cenderung untuk melakukan evaluasi secara cepat-cepat dan bukannya melakukan evaluasi terhadap produk secara seksama (Mittelstaedt dkk., 1976). Deskripsi tersebut sesuai dengan tiga gaya belanja lainnya dari CSI. Salah satu dari gaya belanja itu, yaitu "kesadaran akan produk baru dan fashion" kemungkinan besar akan merasa sangat senang ketika mereka mencari barangbarang baru dalam berbelanja (Zuckerman, 1979). Selain itu, konsumen yang memiliki gaya "kesadaran rekreasional dan hedonistik" memiliki ciri yang membuat mereka merasa bahwa belanja adalah hal yang menyenangkan dan mereka berbelanja semata demi kesenangan berbelanja itu sendiri (just for the fun of it) dimana kegiatan berbelanja dipandang sebagai rekreasi dan hiburan (Sproles dan Kendall, 1986). Karenanya konsumen yang lebih condong beorientasi penghindaran ketidakpastian rendah akan memiliki, kesadaran fashion, orientasi rekreasional, dan impulsif di dalam gaya belanja mereka:

H2; Konsumen yang memiliki kecenderungan pada orientasi penghindaran ketidakpastian rendah cenderung untuk memiliki gaya pengambilan keputusan belanja yang bercirikan: (a) kesadaran fashion, (b) orientasi rekreasional, dan (c) impulsif.

\section{METODE PENELITIAN}

Penelitian ini bertujuan untuk mengembangkan ilmu, yaitu mencari jawaban baru atas keterkaitan penghindaran ketidakpastian dengan gaya keputusan belanja wisatawan. Oleh karena sasaran dalam penelitian ini pada pengembangan ilmu, maka jenis penelitian ini merupakan penelitian dasar (Ferdinand, 2011). Berdasarkan jenis riset termasuk riset kausal, karena ingin mencari penjelasan dalam bentuk hubungan sebab akibat antara beberapa konsep atau beberapa variabel yang dikembangkan dalam manajemen (Ferdinand, 2011).

Data utama yang dibutuhkan dalam penelitian ini berupa data primer yang bersumber dari wisatawan yang sedang berkunjung di Pulau Lombok. Selain itu, digunakan pula data skunder yang dalam penelitian ini merupakan data penunjang yang bersumber dari Dinas Pariwisata, serta publikasi, laporan, dan dokumen lain yang mendukung. Data dikumpulkan melalui kuesioner, yang diberikan secara langsung kepada wisatawan Nusantara (Indonesia) yang sedang melakukan wisata Pulau Lombok. Sedangkan untuk data sekunder yang bersumber dari laporan dan publikasi lainny. Adapun kuesioner yang digunakan mengacu pada penelitian yang dilakukan oleh Yoo \& Dontu (2005) dan Leo, Bennett \& Cartel (2005). 
Populasi dalam penelitian ini adalah seluruh wisatawan Nusantara yang sedang berkunjung di Pulau Lombok. Berdasarkan pertimbangan luasnya wilayah, dan banyaknya jumlah wisatawan, maka teknik sampling yang digunakan adalah purposive sampling, dan fokus pada kawasan Pantai Senggigi, Gili Trawangan, dan Pantai Kuta, dengan pertimbangan konsentrasi kegiatan kepariwisataan yang lebih besar dan lebih banyak. Jumlah responden dalam penelitian ini ditentukan secara purposive sampling sebanyak 100 orang dengan pertimbangan jumlah populasi belum diketahui secara pasti. Adapun kriteria sampel yang dipilih adalah: usia diatas 17 tahun, dan berasal dari luar Pulau Lombok.

Variabel yang akan dianalisis meliputi : (1) Penghindaran Ketidakpastian, (2) Kesadaran Kualitas, (3) Kesadaran harga, (4) Kebingungan karena banyaknya pilihan, (5) Kesadaran merek, (6) Loyalitas merek, (7) Kesadaran Fashion, (8) Rekreasional, (9) Impulsive. Untuk pencapaian tujuan penelitian, data akan dianalisis secara kualitatif dan kuantitatif dengan bantuan komputer yakni menentukan keterkaitan antara tinggi/ rendahnya orientasi penghindaran ketidakpastian dengan gaya pengambilan keputusan wisatawan dalam berbelanja.

\section{HASIL DAN PEMBAHASAN}

\subsection{Karakteristik Responden}

Responden dalam penelitian ini adalah wisatawan Nusantara (domestik) yang sedang melakukan kegiatan wisata di beberapa tempat wisata di Pulau Lombok, yakni; Gili Trawangan, Pantai Senggigi, dan Pantai Kuta. Tabel 1. berikut ini menyajikan deskripsi responden.

Tabel 1.

Deskripsi Responden Berdasarkan Jenis Kelamin, Umur, dan Pendidikan

\begin{tabular}{llrr}
\hline KARAKETRISTIK RESPONDEN & & FREKWENSI & $\%$ \\
\hline JENIS KELAMIN & LAKI & 35 & 35.0 \\
& PEREMPUAN & 65 & 65.0 \\
KELOMPOK UMUR & TOTAL & 100 & 100.0 \\
& $17-25$ & 12 & 12.0 \\
& $26-35$ & 19 & 19.0 \\
PENDIDIKAN & $36-45$ & 30 & 30.0 \\
& $46-55$ & 39 & 39.0 \\
& TOTAL & 100 & 100.0 \\
& SMU & 27 & 27.0 \\
& D3 & 13 & 13.0 \\
JENIS KUNJUNGAN & S1 & 48 & 48.0 \\
& S2 & 12 & 12.0 \\
& TOTAL & 100 & 100.0 \\
& PERTAMA & 57 & 57,00 \\
& ULANG & 43 & 43,00 \\
& TOTAL & 100 & 100,00
\end{tabular}

Sumber : Data Primer Diolah

\subsection{Deskripsi Variabel Penelitian}

Berdasarkan rerata tanggapan responden terhadap variabel yang diukur dalam penelitian ini menunjukkan orientasi terhadap penghindaran ketidakpastian cenderung memiliki level bervariasi. Sebanyak 31 orang responden cenderung memiliki orientasi budaya penghindaran ketidakpastian tinggi, sisanya yakni sebanyak 69 orang memiliki orientasi penghindaran ketidakpastian rendah. Adapun hasil Analisis Manova terkait hipotesis yang diajukan menunjukkan hasil sebagai berikut : 
Tabel 2

Nilai Skor Rata-rata Gaya Keputusan dan Tingkat Penghindaran Ketidakpastian

\begin{tabular}{|l|c|c|r|r|r|r|r|r|}
\hline $\begin{array}{l}\text { Penghindaran } \\
\text { Ketidakpastia } \\
\mathrm{n}\end{array}$ & $\mathrm{Y} 1$ & $\mathrm{Y} 2$ & $\mathrm{Y} 3$ & $\mathrm{Y} 4$ & $\mathrm{Y} 5$ & $\mathrm{Y} 6$ & $\mathrm{Y} 7$ & $\mathrm{Y} 8$ \\
\hline Rendah & 3,11 & 3,25 & 3,25 & 3,30 & 3,21 & $\mathbf{4 , 1 6}$ & $\mathbf{4 , 2 6}$ & $\mathbf{4 , \mathbf { 1 5 }}$ \\
Tinggi & $\mathbf{4 , 0 8}$ & $\mathbf{4 , 0 6}$ & $\mathbf{4 , 0 9}$ & $\mathbf{4 , 0 6}$ & $\mathbf{4 , 0 9}$ & 3,82 & 3,84 & 3,84 \\
Total & $\mathbf{3 , 9 1}$ & $\mathbf{3 , 9 2}$ & $\mathbf{3 , 9 5}$ & $\mathbf{3 , 9 3}$ & $\mathbf{3 , 9 4}$ & $\mathbf{3 , 8 7}$ & 3,91 & 3,89 \\
\hline
\end{tabular}

Sumber: data Primer diolah

Tabel 2 menyajikan Deskripsi data berdasarkan nilai rata-rata, pada tiap kelompok. Kelompok penghindaran ketidakpastian rendah lebih dicirikan pada tingginya Y6, Y7 dan $Y 8$, yakni sebesar; 4,16; 4,26, dan 4,15. Sedangkan pada kelompok tinggi lebih dicirikan pada Y1 $(4,08)$, Y2 $(4,06)$, Y3 $(4,09), Y 4(4,06)$ dan Y5 $(4,09)$.

Hasil MANOVA untuk menguji adanya perbedaan secara multivariate pada Y1 - Y8 berdasarkan kelompok penghindaran ketidakpastian dapat dibuktikan melalui statistik Pillai Trace, Wilks Lambda, Hotelling Trace atau Roy's Largest Root. Tingkat signifikansi yang terhitung dari keempat statistik tersebut adalah sig $<0,001$ atau $p<0,001$. Hasil ini memberikan interpretasi bahwa secara multivariate, ada perbedaan rata-rata Y1-Y8 antara kelompok penghindaran ketidakpastian rendah dan tinggi, yang ditunjukkan pada tabel di bawah ini :

Tabel 3

Hasil MANOVA

\begin{tabular}{|c|c|c|c|c|c|c|}
\hline \multicolumn{2}{|l|}{ Effect } & Value & $\mathrm{F}$ & $\begin{array}{l}\text { Hypothesis } \\
\text { df }\end{array}$ & Error df & Sig. \\
\hline \multirow{4}{*}{ Intercept } & Pillai's Trace & ,988 & $931,592^{b}$ & 8,000 & 91,000 & , 000 \\
\hline & Wilks' Lambda & ,012 & $931,592^{b}$ & 8,000 & 91,000 & ,000 \\
\hline & Hotelling's Trace & 81,898 & $931,592^{b}$ & 8,000 & 91,000 & ,000 \\
\hline & $\begin{array}{l}\text { Roy's Largest } \\
\text { Root }\end{array}$ & 81,898 & $931,592^{b}$ & 8,000 & 91,000 & ,000 \\
\hline \multirow{4}{*}{ Grup } & Pillai's Trace &, 589 & $16,285^{b}$ & 8,000 & 91,000 & ,000 \\
\hline & Wilks' Lambda & ,411 & $16,285^{b}$ & 8,000 & 91,000 & ,000 \\
\hline & Hotelling's Trace & 1,432 & $16,285^{b}$ & 8,000 & 91,000 & ,000 \\
\hline & $\begin{array}{l}\text { Roy's Largest } \\
\text { Root }\end{array}$ & 1,432 & $16,285^{b}$ & 8,000 & 91,000 & ,000 \\
\hline
\end{tabular}

Sumber: data primer diolah

\subsection{Pembahasan}

\subsubsection{Penghindaran ketidakpastian tinggi dan Gaya pengambilan keputusan}

Berdasarkan hasil Analisis Manova membuktikan adanya keterkaitan tinggi rendahnya level orientasi budaya penghindaran ketidakpastian dengan gaya pengambilan keputusan konsumen (wisatawan) dalam melakukan kegiatan belanja. Orientasi penghindaran ketidakpastian yang tinggi merefleksikan tingginya perasaan terancam dengan situasi yang penuh ketidakpastian, tidak bisa diprediksi dan tidak jelas. Wisatawan 
dengan orientasi penghindaran ketidakpastian tinggi cenderung memiliki perasaan yang sangat tidak nyaman dengan lingkungan yang tidak pasti dan ambigu.

Gayabelanja yang "perfeksionisme", menunjukkan preferensi dari konsumen yang mencari kualitas tertinggi dalam produk. Konsumen yang peka kualitas (quality conscious) akan mencari produk dengan kualitas terbaik dengan cara berbelanja secara sistematis dan seksama (Sproles \& Kendall, 1986). Produk berkualitas tinggi bagi mereka menjadi jaminan akan terpenuhinya harapan mereka pada suatu produk,dan besar kemungkinan terhindar dari resiko kerugian finansial, manfaat yang akan diperoleh, maupun ketidakpuasan dari hasil mengkonsumsi produk.

Menurut Kotler dan Amstrong (2008) kualitas adalah karakteristik dari produk dalam kemampuan untuk memenuhi kebutuhan-kebutuhan yang telah ditentukan dan bersifat laten. Sedangkan menurut Garvin dan A. Dale Timpe (1990, dalam Alma, 2011) kualitas adalah keunggulan yang dimiliki oleh produk tersebut. Dengan demikian kualitas dari sebuah produk dalam pandangan konsumen adalah hal yang dapat meberikan mereka jaminan terpenuhinya harapan mereka pada produk yang dibeli, baik menyangkut kehandalan, daya tahan, manfaat, nilai dan sebagainya.

Para konsumen yang memiliki kesadaran harga yang lebih tinggi akan lebih keras usahanya untuk mendapatkan nilai terbaik bagi uang mereka dan kemungkinan besar akan melakukan perbandingan dalam berbelanja. Resiko ketidaksesuaian manfaat dengan pengorbanan yang dikeluarkan bisa saja muncul dalam kegiatan belanja. Karena itu bagi individu yang berorientasi pada penghindaran ketidakpastian tinggi cenderung untuk menunjukkan gaya belanja yang peka terhadap harga, yaitu "keengganan/ ketidakbersediaan"(unwillingness) dari pembeli untuk membayar harga yang lebih tinggi untuk sebuah produk dan/atau "fokus secara eksklusif" semata-mata pada membayar harga rendah (Lichtenstein, Ridgway dan Netemeyer, 1993:235).

Terlalu banyak pilihan dapat menyebabkan konsumen tertentu merasa kebingungan. Mereka terpapar oleh berbagai stimulus seperti produk, merek, harga, toko yang menawarkan dengan berbagai strategi yang berbeda. Kemudian, konsumen yang "bingung karena terlalu banyak pilihan" akan memperhatikan banyak merek dan banyak toko yang hendak mereka pilih, sehingga mereka mengalami kelebihan beban informasi (information overload). Dalam proses pengambilan keputusan konsumen untuk berbelanja, hasil dari rangsangan ini akan diatur oleh OSL, yang merupakan kecenderungan individu untuk merespon rangsangan lingkungan (Swati dan Sandeep, 2012).

Optimum Stimulation Level adalah kepemilikan yang mencirikan individu dalam hal respon umum terhadap rangsangan lingkungan (Leuba, 1955 dalam Sharma, Sivakumaran, Marshall, 2010). OSL berkorelasi positif dengan berbagai perilaku eksplorasi dalam konteks konsumen, seperti mengadopsi produk baru, beralih merek, mengambil risiko, dan mencari informasi dari keingintahuan. Individu dengan OSL tinggi mengalami dorongan untuk mencari rangsangan tambahan dari lingkungan dengan mencari berbagai atau mengambil risiko bila rangsangan yang berada di lingkungan kurang optimal. Jika dihubungkan antara optimum stimulation level dengan impulsive buying maka individu dengan optimum stimulation level yang tinggi cenderung melakukan hal baru ketika berbelanja seperti mengadopsi produk baru (Raju, 1980 dalam Sharma, Sivakumaran, Marshall, 2010).

Seorang individu dengan orientasi budaya penghindaran ketidakpastian tinggi, cenderung akan merasa kebingungan karena mereka takut menghadapi resiko, cenderung banyak mempertimbangkan konsekwensi yang akan diterma dari hasil sebuah keputusan pembelian. Pengambilan keputusan secara peka terhadap merek merujuk pada orientasi konsumen yang cenderung untuk membeli produk yang mahal dan memiliki merek terkenal. Merek (brand) terkenal adalah jaminan terhadap kualitas dari sebuah produk. 
Merek yang terkenal mengekspresikan kekuatan dari merek tersebut, dan menjadi citra bagi produk, perusahaan, dan pemakainya. Kesetiaan merek adalah sebuah strategi untuk mengurangi resiko, dan ini konsisten dengan dimensi UAI (keengganan terhadap ketidakpastian) dari Hofstede (2001) karena perilaku menghindari ketidakpastian akan memperbesar keengganan (aversion) terhadap resiko (Yau, 1988). Konsumen-konsumen yang memiliki UAI tinggi lebih suka menghindari ketidakpastian dan akan lebih besar kemungkinannya untuk menggunakan merek-merek yang sudah dikenal baik untuk mengurangi ketidakpastian atau ambiguitas.

\subsubsection{Penghindaran ketidakpastian rendah dan gaya pengambilan keputusan}

Konsumen yang berorientasi pada penghindaran ketidakpastian rendah suka akan hal yang baru dan cenderung untuk memiliki sikap yang santai terhadap kehidupan, berani mengambil resiko dan melakukan hal-hal yang bisa memberikan kesenangan tanpa berpikir banyak atau berpikir panjang (Zuckerman, 1979). Zuckerman (1979) mendapati bahwa para pencari sensasi ini bersifat impulsif, yaitu cenderung untuk bertindak berdasarkan kemauan yang dirasakan saat itu juga. Para pemikir dengan sensasi tinggi ini cenderung untuk melakukan evaluasi secara cepat-cepat dan bukannya melakukan evaluasi terhadap produk secara seksama (Mittelstaedt dkk., 1976). Deskripsi tersebut sesuai dengan tiga gaya belanja lainnya dari CSI. Salah satu dari gaya belanja itu, yaitu "kesadaran akan produk baru dan fashion" kemungkinan besar akan merasa sangat senang ketika mereka mencari barangbarang baru dalam berbelanja (Zuckerman, 1979). Selain itu, para konsumen yang mencari kesenangan/ kepuasan (gratification) dalam perilaku yang memiliki nuansa petualangan akan lebih besar kemungkinannya untuk membeli produk baru (Goldsmith, 1983).

Selain itu, konsumen yang memiliki gaya "kesadaran rekreasional dan hedonistik" memiliki ciri yang membuat mereka merasa bahwa belanja adalah hal yang menyenangkan dan mereka berbelanja semata demi kesenangan berbelanja itu sendiri (just for the fun of it) dimana kegiatan berbelanja dipandang sebagai rekreasi dan hiburan (Sproles dan Kendall, 1986). Hedonisme adalah pandangan hidup yang menganggap bahwa orang akan menjadi bahagia dengan mencari kebahagiaan sebanyak mungkin dan sedapat mungkin menghindari perasaan-perasaan yang menyakitkan, dan memandang kesenangan atau kenikmatan merupakan tujuan hidup dan tindakan manusia. Kesenangan, kenyaman, yang diinginkan ditunjukkan pula pada kegiatan belanja. Mereka senang mencoba produk baru (fashionable), tidak mempertimbangkan banyak hal sebagi konsekuensi dan resiko keputusan belanja mereka, dan menikmati kegiatan berbelanja.

Orientasi penghindaran ketidakpastian yang rendah kemungkinan besar memiliki ambang batas toleransi yang lebih tinggi terhadap resiko dan ketidakpastian. Individu dalam berperilaku menampilkan perilaku yang menghindari risiko dan perilaku mencari risiko di berbagai macam situasi (Dowling, 1986 dalam Soares, 2004). Perspektif perilaku eksplorasi risiko mengasumsikan bahwa konsumen dapat mencari risiko untuk meningkatkan kompleksitas stimulus untuk melarikan diri kebosanan (Cox, 1967, Hoyer \& Ridgway, 1984; Dowling, 1986 dalam Soares, 2004). Demikian pula, Zuckerman, 1994 dalam Soares (2004) menyatakan bahwa pengambilan risiko berkorelasi dengan mencari sensasi, individu bersedia menerima risiko yang terkait dengan pengalaman baru dan intens. Oleh karena itu semakin rendah tingkat penghindaran ketidakpastian individu, semakin meningkat kebutuhan untuk mencari sensasi, pengalaman baru, dan tantangan yang dapat memberikan sensasi maupun melarikan diri dari kebosanan yang dirasakan.

Karenanya konsumen yang lebih condong beorientasi penghindaran ketidakpastian rendah akan memiliki gaya pengambilan keputusan yang dicirikan dengan, kesadaran fashion, orientasi rekreasional, dan impulsif. Mendapatkan pengalaman, sensasi, kesenangan baru, bagi wisatawan dengan orientasi penghindaran ketidakpastian rendah 
menjadi implikasi dari oreintasi budaya yang ada pada diri individu. Pada level orientasi penghindaran ketidakpastian yang rendah, mereka cenderung tidak banyak mempertimbangkan berbagai hal dan kemungkinan resiko serta konsekwensi dari keputusan yang diambil.

\section{SIMPULAN DAN IMPLIKASI}

Pengukuran orientasi budaya pada wisatawan menunjukkan variasi level orientasi penghindaran ketidakpastian yang ditunjukkan pada level rendah dan tinggi. Implikasi dari orientasi yang bervariasi tersebut, berakibat pada kecenderungan gaya pengambilan keputusan pada wisatawan. Sesuai dengan tujuan penelitian ini dan dari Analisis Manova membuktikan bahwa: Wisatawan dengan orientasi budaya penghindaran ketidakpastian tinggi cenderung menunjukkan gaya pengambilan keputusan pembelian yang cenderung mementingkan kualitas, kesadaran pada nilai (harga), kebingungan karena pilihan yang terlalu banyak, kesadaran merek, dan kesetiaan merek. Sedangkan wisatawan yang memiliki orientasi penghindaran ketidakpastian rendah cenderung untuk memiliki gaya pengambilan keputusan belanja yang bercirikan: kesadaran fashion, orientasi rekreasional, dan impulsif.

Hasil penelitian ini memperkuat hasil penelitian sebelumnya terkait dengan perbedaan gaya belanja yang terjadi pada konsumen dan indikasi adanya pengaruh kuat dari latar belakang budaya individu. Hasil penelitian ini memberikan implikasi bagi pelaku bisnis sektor pariwisata maupun berbagai pihak yang berkepentingan dalam kegiatan tersebut, diantaranya :

1. Para pengambil kebijakan dan pelaku bisnis industri pariwisata, diharapkan untuk lebih memperhatikan orientasi budaya wisatawan sebagai salah faktor yang berhubungan dengan gaya pengambilan keputusan wisatawan dalam berbelanja

2. Pelaku bisnis pariwisata hendaknya meningkatkan kualitas produk, mengutamakan nilai produk, memperkuat merek, melakukan inovasi produk secara berkelanjutan, serta merancang kegiatandan lokasi yang senyaman mungkin bagi wisatawan.

3. Bagi peneliti selanjutnya, diharapkan dapat mengembangkan penelitian ini pada kelompok wisatawan yang berbeda, atau dengan dimensi budaya lainnya, sehingga dapat memberikan kontribusi bagi pengembangan pemahaman perilaku wisatwan terutama terkait dengan latar belakang budaya mereka.

\section{DAFTAR PUSTAKA}

Anonim, Statistik Kebudayaan dan Pariwisata Provinsi Nusa Tenggara Barat Tahun 2012, Dinas Kebudayaan dan Pariwisata Provinsi Nusa Tenggara Barat

Leo, Bennet, Hartel, (2005), Cross Cultural Differences in Consumer Decision Making Style

Dimanche, F. (2003), “The Louisiana tax free shopping program for international visitors: a case study", Journal of Travel Research, Vol. 41 No. 3, pp. 311-314

Fan, J. X., \& Xiao, J. J. (1998). Consumer decision-making styles of young Chinese. The Journal of Consumer Affairs, 32 (2), 275-294.

Ferdinand Augusty,(2011), Metode Penelitian Mananajemen, Pedoman untuk Penulisan Skripsi, Tesis, dan Disertasi Ilmu Manajemen, Edisi 3, Seri Pustaka Kunci 10/2011, BP Undip, ISBN 979-704-254-5 
Hiu, A. S. Y., Siu, N. Y. M., Wang, C. C. L., \& Chang, L. M. K. (2001). An investigation of decision-making styles of consumers in China. The Journal of Consumer Affairs, 35 (2), 326-346.

Hofstede, (1983), The Cultural Relativity of Organizational Practices and Theories, Journal Of International Business Studies, JStor

Hofstede, G. (2001). Culture's consequences: Comparing Values Behaviors, Institutions and Organizations Across Nations. London: Sage Publications.

Jansen-Verbeke, M. (1991), "Leisure shopping: a major concept for the tourism industry?",Tourism Management, Vol. 12 No. 1, pp. 9-14.

Jansen-Verbeke, M. (1998). "The synergism between shopping and tourism", in Theobald, W. F. (Ed.), Global Tourism: The Next Decade, 2nd ed., Oxford, UK: ButterworthHeinemann, pp. 347-362.

Jung-Oh, Yoon, (2007), An Exploration of Tourist Shopping, Disertation for the degree of Doctor of Philosopy, M University

Kotler, Phillip, (2003), Marketing Management, Eleventh Edition, International Edition, Prentice Hall

Lowe, A. C. T., \& Corkindale, D. R. (1998). Differences in "cultural values" and their effects on responses to marketing stimuli: A cross-cultural study between Australians and Chinese from the People's Republic of China. European Journal of Marketing, 32 (9/10), 843-867.

Littrell, M.A., Baizerman, S., Kean, R., Gahring, S., Niemeyer, S., Reilly, R., and Stout, J.A. (1994), "Souvenirs and tourism styles", Journal of Travel Research, Vol. 33 No. 1, pp. 3- 11.

Lysonski.S, Durvasula. S, Zotos, Y, (1996), Consumer decision-making styles: a multi-country , European Journal of Marketing Vol. 30 Iss: 12 pp. 10 - 21, Emerald Article

Meng, Xu, (2012),"Tourism Shopping Behavior: Planned, Impulsive, or Experiential?", International Journal of Culture, Tourism and Hospitality Research, Vol. 6 Iss: 3 pp. 5 $-5$

Money, Crotts, (2003), The Effect of Uncertainty Avoidance on Information Search,Planning, and Purchases of International Travel Vacations, Journal Tourism Management,

Pariwisata Indonesia, Newsletter Informasi Pemasaran Pariwisata, Volume 3 No. 30, Juni 2012

Pearce, L. Philip, (2005), Tourist Behavior; Themes and Conceptual Schemes, Cromwell Pres

Schifman, Leon, Kanuk, (2007), Consumer Bahavior,7thEd, Kasip, Zoelkifli (penerjemah), Perilaku Konsumen, Edisi Ketujuh, Indeks, Jakarta

Spears, N., Lin, X., \& Mowen, J. C. (2001). Time orientation in the United States, China and Mexico: Measurement and insights for promotional strategy. Journal of International Consumer Marketing, 13 (1), 57-75.

Sproles, G. B., \& Kendall, E. L. (1986). A methodology for profiling consumers' decisionmaking styles. The Journal of Consumer Affairs, 20 (2), 267-279.

Timothy, D. and Butler, R. (1995), "Cross-border shopping: a North American perspective", Annals of Tourism Research, Vol. 22 No. 1, pp. 16-34.

Westbrook, R. A., \& Black, W. C. (1985). A motivation-based shopping typology. Journal of Retailing, 61 (1), 78-101.

Yau, 0. H. M. (1988). Chinese cultural values: Their dimensions and marketing implications. European Journal of Marketing, 22 (5), 44-57. 
Yie Leng,Botelho, (2010), How Does National Culture Impact on Consumers' Decisionmaking Styles? A Cross Cultural Study in Brazil, the United States and Japan, BAR, Curitiba, v. 7, n. 3, art. 3, pp. 260-275, July/Sept. 2010

Yoo, Donthu, dan Lenartowicz (2011), Measuring Hofstede's Five dimensions of Cultural Values at the Individual Level : development and Validation of CVSCALE,Journal of International Consumer Marketing, 23:3-4, 193-210 